Міцода Р.М.

\title{
Прогнозування акушерських ускладнень у жінок з вперше виявленою реплікативною активністю гепатиту В
}

\author{
ДВНЗ «Ужгородський національний університет», м. Ужгород, Україна
}

rmitsoda@gmail.com

\author{
Мицода Р.М. \\ Прогнозирование акушерских осложнений \\ у женщин с впервые выявленной репликативной \\ активностью гепатита В \\ ГВУЗ «Ужгородский национальный университет»
}

\author{
Mitsoda R.M. \\ Prediction of obstetric complications \\ in women with newly discovered hepatitis B \\ repetitive activity \\ SU "Uzhhorod National University"
}

\section{Вступ}

Не дивлячись на досягнення медицини та постійне впровадження нових медичних технологій у практику 3 метою контролю над інфекційними процесами, вірусні гепатити $\epsilon$ суттєвою причиною підвищення захворюваності та смертності [1-4]. На сьогодні у світі 1 млрд інфікованих та 350 млн чоловік носіїв вірусу ГВ, які є постійним резервуаром та джерелом інфекції [5].

Мета роботи - простежити перебіг вагітності, пологів, післяродового періоду у жінок 3 вперше виявленою ре плікативною активністю гепатиту В під час вагітності та ранній неонатальний період їх новонароджених для прогнозування та попередження акушерських ускладнень.

\section{Клінічний матеріал та методи дослідження}

Проведене комплексне обстеження 43 жінок, які страждали на гострий гепатит В протягом вагітності та їх новонароджених і 100 соматично здорових жінок жінок та їх новонароджених.

Групи жінок є однорідними за віком, соціальним станом (жінки заміжні), в певній мірі за спеціальністю (домогосподині, або працюють за фахом, що не пов'язаний $з$ фізичними навантаженнями та контактом 3 тератогенними речовинами), проживають у межах одного часового поясу та умовах помірно-континентального клімату.

Статистична обробка результатів спостереження проведена за допомогою пакетів програм STATISTICA 5.0 тa Excel 6.0. Для обчислення прогностичної значимості ознак був використаний критерій Стьюдента у модифікації Амосова Н.М. та співавторів (1975 р.).

Для інтегральної оцінки ускладнень виділяли i систематизували ускладнення гестаційного процесу, що є найбільш значущими на погляд акушера:
- під час вагітності - загроза самовільного викидня, загроза пізнього самовільного викидня, загроза передчасних родів, ранній токсикоз, гестаційний набряк, прееклампсія, пієлонефрит, плацентарна недостатність, анемія, гострі респіраторно-вірусні інфекції, наркоманія;

- під час пологів та післяродового періоду передчасні роди, переношена вагітність, швидкі пологи, слабість родових сил, неефективність родозбудження, родозбудження, родопідсилення, дородове та раннє злиття навколоплідних вод, дефект плаценти та/або оболонок, ручна або інструментальна ревізії порожнини матки, гіпотонія, гіпертермія, анемія, післяродовий ендометрит, лохіометра, багато- та маловіддя, зелені або меконіальні навколоплідні води;

- стосовно стану плода - антенатальна загибель, асфіксії, кефалогематоми, перелом ключиці, гостре ішемічне ураження ЦНС, гіпорефлексія, синдром дихальних розладів, ціанози, внутрішньоутробна гіпотрофія, недоношенсть, незрілість, гемолітична або кон'югаційна жовтяниці, абстинентний синдром та парез Ерба.

\section{Результати дослідження та їх обговорення}

Усі жінки 3 вперше виявленою реплікативною активністю збудника гепатиту В під час вагітності були поділені на дві групи:

- 3 акушерськими ускладненнями в пологах;

- без патологічних акушерських змін протягом родового акту.

На основі аналізу 54 факторів відібрали 12 найбільш значущих факторів для прогнозування виникнення акушерських ускладнень в пологах саме для жінок з вперше виявленою реплікативною активністю ГВ під час гестації. Причому, загально добиралися фактори, що $є$ простими у спостереженні та доступними для лікаря навіть в умовах жіночої консультації (табл. 1). 
Таблиця 1. Прогностична значимість факторів, які визначають акушерські ускладнення в пологах у жінок $з$ вперше виявленою реплікативною активністю збудника ГВ під час вагітності

\begin{tabular}{|c|c|c|c|c|c|c|c|}
\hline \multirow{3}{*}{$\begin{array}{l}\text { № } \\
\text { п/ா/ }\end{array}$} & \multirow{3}{*}{ Фактор } & \multirow{3}{*}{$\begin{array}{l}\text { Кількість } \\
\text { випадків }\end{array}$} & \multicolumn{3}{|c|}{ Результат } & \multirow{3}{*}{$\begin{array}{c}\text { Середня } \\
\text { частота } \\
\text { несприятливих } \\
\text { результатів, \% }\end{array}$} & \multirow{3}{*}{$\begin{array}{c}\text { Значення, } \\
\text { бали }\end{array}$} \\
\hline & & & \multirow{2}{*}{$\begin{array}{l}\text { Добрий } \\
\text { осіб }\end{array}$} & \multicolumn{2}{|c|}{ Несприятливий } & & \\
\hline & & & & осіб & $\%$ & & \\
\hline 1 & $\begin{array}{l}\text { Плацентарна } \\
\text { недостатність }\end{array}$ & 3 & 0 & 3 & 100 & 47,5 & 1,80 \\
\hline 2 & $\begin{array}{l}\text { Загроза пізнього } \\
\text { самовільного викидня }\end{array}$ & 9 & 2 & 7 & 77,8 & 47,5 & 1,41 \\
\hline 3 & $\begin{array}{l}\text { Підвищення рівня } \\
\text { АлАТ більш } \\
\text { ніж у } 3 \text { норми }\end{array}$ & 12 & 3 & 9 & 75,0 & 47,5 & 1,23 \\
\hline 4 & $\begin{array}{l}\text { Загроза самовільного } \\
\text { викидня }\end{array}$ & 7 & 1 & 6 & 85,7 & 47,5 & 1,20 \\
\hline 5 & $\begin{array}{l}\text { Наявність } \\
\text { екстрагенітальної } \\
\text { патології }\end{array}$ & 7 & 1 & 6 & 85,7 & 47,5 & 1,20 \\
\hline 6 & Вік до 20 років & 13 & 4 & 9 & 69,2 & 47,5 & 1,19 \\
\hline 7 & $\begin{array}{l}\text { Артифіційні } \\
\text { переривання } \\
\text { в анамнезі }\end{array}$ & 8 & 2 & 6 & 75,0 & 47,5 & 1,16 \\
\hline 8 & $\begin{array}{l}\text { Підвищення рівня } \\
\text { загального білірубіну } \\
\text { більше } 100 \text { мкмоль/л }\end{array}$ & 8 & 2 & 6 & 75,0 & 47,5 & 1,16 \\
\hline 9 & $\begin{array}{l}\text { Підвищення рівня } \\
\text { АсАТ більш } \\
\text { ніж у } 3 \text { норми }\end{array}$ & 8 & 2 & 6 & 75,0 & 47,5 & 1,16 \\
\hline 10 & $\begin{array}{l}\text { Гострі респіраторно- } \\
\text { вірусні інфекції } \\
\text { під час вагітності }\end{array}$ & 1 & 0 & 1 & 100 & 47,5 & 1,02 \\
\hline 11 & $\begin{array}{l}\text { Самовільні викидні } \\
\text { в анамнезі }\end{array}$ & 1 & 0 & 1 & 100 & 47,5 & 1,01 \\
\hline 12 & $\begin{array}{l}\text { Гепатит важкого } \\
\text { ступеню }\end{array}$ & 1 & 0 & 1 & 100 & 47,5 & 1,01 \\
\hline
\end{tabular}

У табл. 1 наведено фактори лише 3 позитивними значеннями, тобто ті, які погіршують прогноз. У звязку з відносно невеликою кількістю хворих з вперше виявленою реплікативною активністю збудника ГВ, що пояснюється невеликою частотою у популяції, а тим більше при поєднанні з вагітністю, низка ознак, наведених у таблиці, також траплялася рідко. Однак їхня клінічна важливість не викликає сумнівів. Значущість їх у балах визначали за допомогою евристичного оцінювання.

Надалі у процесі диспансеризації чи для короткострокового прогнозування, додавали показники прогностично важливих ознак (бали). 3 огляду на небезпеку неправильного збільшення суми балів за рахунок застосування тісно взаємопов'язаних факторів, перевіряли кореляційні звязки між вибраними клінічними показниками. 3'ясувалося, що істотного звязку між ними немає (у жодному випадку коефіцієнт кореляції не перевищував 0,3).

Слід зазначити, що значна кількість факторів ризику узгоджується 3 літературними даними, що в основному характеризують важкість запалення печінки вірусного генезу (підвищення рівня аланін- та амінотрансферази, рівня загального білірубіну та ступінь важкості гепатиту) та такі, що окреслюють “масивність" гінекологічного анамнезу жінки (наявність в анамнезі артифіційних переривань та самовільних викиднів).

Для практичної зручності у процесі передбачення перебігу пологів у вагітних 3 вперше виявленою реплікативною активністю ГВ виділяли чотири ступені ймовірності несприятливого результату:

- І ступінь - сума балів меньше 1,5;

- II ступінь - 1,5-3 бала;

- III ступінь - 3,1-4,5 бала;

- IV ступінь - >4,5 бала.

Додаючи показники ознак кожного пацієнта, визначали загальну суму балів. Поділ вагітних у залежності від суми балів наведено в табл. 2 .

Встановлено статистично достовірне збільшення ймовірності несприятливих результатів у міру зростання ступеня ризику (рис.). 
Таблиця 2. Залежність ймовірності виникнення акушерських ускладнень у вагітних з вперше виявленою реплікативною активністю ГВ від ступеня ризику

\begin{tabular}{|c|c|c|c|c|c|c|}
\hline \multirow{3}{*}{$\begin{array}{l}\text { Ступінь } \\
\text { ризику }\end{array}$} & \multirow{3}{*}{ Сума балів } & \multirow{3}{*}{$\begin{array}{c}\text { Кількість } \\
\text { спостережень }\end{array}$} & \multicolumn{3}{|c|}{ Результат } & \multirow{3}{*}{$\begin{array}{c}\text { Середня теоретична } \\
\text { частота } \\
\text { несприятливих } \\
\text { результатів, \% }\end{array}$} \\
\hline & & & \multirow{2}{*}{ Сприятливий } & \multicolumn{2}{|c|}{ Несприятливий } & \\
\hline & & & & оciб & $\%$ & \\
\hline I & $<1,5$ & 23 & 19 & 4 & 21,1 & $<21,1$ \\
\hline II & $1,5-3$ & 6 & 2 & 4 & 66,7 & 66,7 \\
\hline III & $3,1-4,5$ & 8 & 2 & 6 & 75,0 & 75,0 \\
\hline IV & $>4,5$ & 6 & 0 & 6 & 100 & 100 \\
\hline Усього & & 43 & 23 & 20 & 47,5 & \\
\hline
\end{tabular}

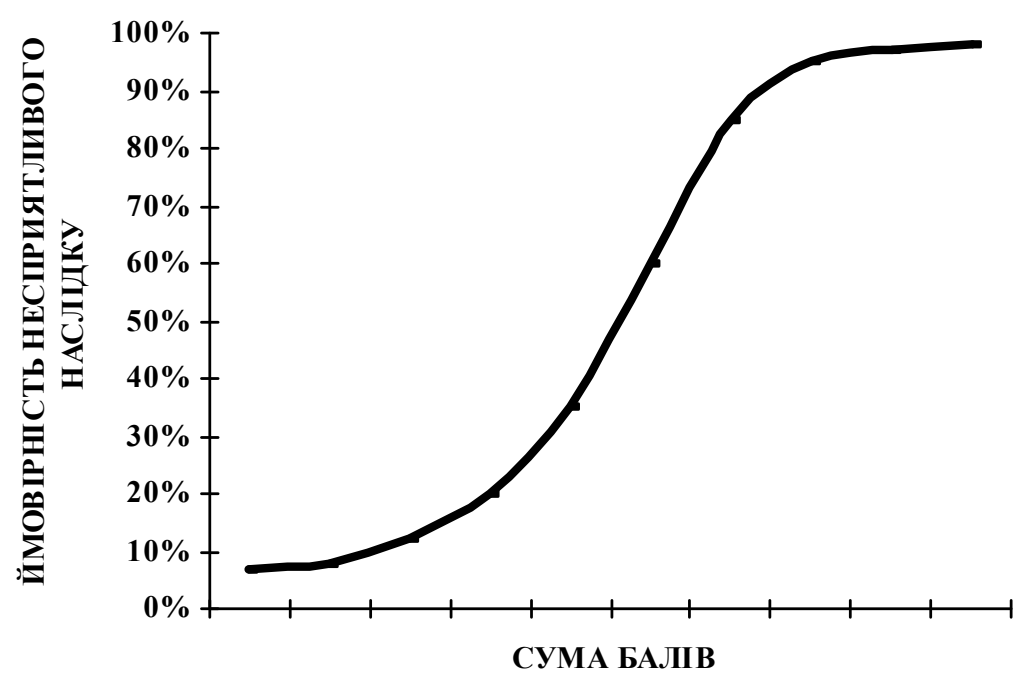

Рис. Загальний вигляд залежності ймовірності несприятливого результату від суми балів ризику

Як бачимо 3 табл. 2, при I ступені ризику ймовірність виникнення акушерських ускладнень не перевищує 21,1\%, тоді як вже при II ступені він сягає $66,7 \% \quad(\mathrm{p}<0,05)$. Таке різке зростання ймовірності виникнення ускладнень свідчить, про необхідність пошуку додаткових факторів ризику для забезпечення більш плавного підвищення інтегрального ризику ускладнень. 3 іншого боку, можна стверджувати, що визначення II, а тим більше III чи 4 потребує обовязкового застосування профілактичних заходів у системі надання медичної допомоги жінкам 3 вперше виявленою реплікативною активністю ГВ.

Слід зауважити, що поява гепатиту ще не означає невідворотності акушерських ускладнень у цих вагітних. Навіть наявність високого ступеня ризику не обовязково призводить до виникнення ускладнень. Показовим з цього приводу є перебіг гестаційного процесу у хворої Ш., 22 років. Жінка перенесла у 15-17 тижнів вагітності гострий вірусний гепатит В середнього ступеня важкості, жовтушну форму. У даної пацієнтки спостерігалися 3 встановлених нами фактори - наявність екстрагенітальної патології (міокардіодистрофія, пролапс мітрального клапану, хронічний холецистит та гіперплазія щитовидної залози I ст.), підвищення рівня загального білірубіну більше 100 мкмоль/л (максимальний рівень білірубіна становив
196,08 мкмоль/л) та середня ступінь важкості гепатиту) i сума балів $(3,56)$ відповідала III ступеню ризику, але пологи пройшли без аналізованих нами ускладнень.

Подальшого дослідження потребують додаткові фактори, що визначають виникнення ускладнень гестаційного процесу у вагітних з гострим гепатитом В.

\section{Висновки}

Ймовірність виникнення акушерських ускладнень статистично вірогідно $(\mathrm{p}<0,05)$ збільшується у міру зростання ступеня ризику. При I ступені ризику ймовірність виникнення акушерських ускладнень не перевищує 25,1\%, тоді як вже при II ступені він сягає $66,7 \% \quad(p<0,05)$. Таке різке підвищення ймовірності виникнення ускладнень в пологах у жінок 3 гострим гепатитом В протягом вагітності свідчить про необхідність пошуку додаткових факторів ризику для забезпечення більш плавного підвищення інтегрального ризику ускладнень. 3 іншого боку, можна стверджувати, що визначення II, а тим більше III чи IV ступеня ризику потребує обов'язкового застосування профілактичних заходів у системі надання медичної допомоги жінкам 3 даною патологією. 


\title{
References
}

1. Castillo E., Murphy K., Shalkwyk J. Hepatitis B and pregnancy // Journal of Obstetrics and Gynecology Canada. 2017. - V. 39. - P. 181-190.

2. Jin J. Screening for Hepatitis B in Pregnant Women // JAMA. 2019;322(4):376. doi:10.1001/jama.2019.9229.

3. Menzo S., Minosse C., Vincenti D. Long-Term Follow-Up of Acute Hepatitis B: New Insights in Its Natural History and Implications for Antiviral Treatment // Genes (Basel). - 2018. - № 9 (6). - PubMed ID 29895748P.

4. Yang L., Wu T., Li J., Xin J. Artificial liver treatment improves survival in patients with hepatitis B-related acute-onchronic liver failure: a case-control matched analysis // Hepatol Res. - 2020. - PubMed ID 3213453.

5. Zhang X., Ying Y., Zhou P., Liu X. A Stepwise Evaluation of Hepatitis B Virus-Related Acute-on-Chronic Liver Failure to Optimize the Indication for Urgent Liver Transplantation // Dig Dis Sci. - 2020. - PubMed ID 32140946.

Дата надходження рукопису до редакції: 06.03.2020 p.

\begin{abstract}
Мета роботи - простежити перебіг вагітності, пологів, післяродового періоду у жінок з вперше виявленою реплікативною активністю гепатиту В під час вагітності та ранній неонатальний період їх новонароджених для прогнозування та попередження акушерських ускладнень.

Проведене обстеження 43 жінок, які страждали на гострий гепатит В протягом вагітності та їх новонароджених і 100 соматично здорових жінок та їх новонароджених. Усі жінки 3 вперше виявленою реплікативною активністю збудника гепатиту В під час вагітності були поділені на дві групи: з акушерськими ускладненнями в пологах та без патологічних акушерських змін протягом родового акту. На основі аналізу 54 факторів відібрали 12 найбільш значущих факторів для прогнозування виникнення акушерських ускладнень в пологах саме для жінок з вперше виявленою реплікативною активністю ГВ під час гестації. Ймовірність виникнення акушерських ускладнень статистично вірогідно (р<0,05) збільшується у міру зростання ступеня ризику. При І ступені ризику ймовірність виникнення акушерських ускладнень не 1перевищує 21,1\%, тоді як вже при II ступені він сягає $66,7 \%$ (p<0,05).
\end{abstract}

Ключові слова: гепатит, прогнозування, ускладнення.

Цель работы - проследить ход беременности, родов, послеродового периода у женщин с впервые выявленной репликативных активностью гепатита В во время беременности и ранний неонатальный период их новорожденных для прогнозирования и предупреждения акушерских осложнений.

Проведено обследование 43 женщин, страдающих острым гепатитом В в течение беременности и их новорожденных и 100 соматически здоровых женщин женщин и их новорожденных. Все женщины с впервые выявленной репликативной активностью возбудителя гепатита В во время беременности были разделены на две группы: с акушерскими осложнениями в родах и без патологических акушерских изменений в течение родового акта. На основании анализа 54 факторов отобрали 12 наиболее значимых факторов для прогнозирования возникновения акушерских осложнений в родах именно для женщин с впервые выявленной репликативной активностью ГВ во время гестации. Вероятность возникновения акушерских осложнений статистически достоверно $(\mathrm{p}<0,05)$ увеличивается по мере роста степени риска. При I степени риска вероятность возникновения акушерских осложнений не превышает $21,1 \%$, тогда как уже при II степени он достигает $66,7 \%$ (p $<0,05$ ).

Ключевые слова: гепатит, прогнозирование, осложнения.

The goal of the work - to trace the course of pregnancy, childbirth, postpartum period in women with newly discovered hepatitis B replicative activity during pregnancy and early neonatal period of their newborns to predict and prevent obstetric complications.

A survey of 43 women who suffered from acute hepatitis B during pregnancy and their newborns and 100 somatically healthy female women and their newborns. All women with newly identified hepatitis B pathogenic activity during pregnancy were divided into two groups: obstetric complications in childbirth and no pathological obstetric changes during the birth act. Based on the analysis of 54 factors, the 12 most significant factors were selected to predict the occurrence of obstetric complications in childbirth, specifically for women with newly diagnosed HS replicative activity during gestation. The probability of obstetric complications is statistically significant $(\mathrm{p}<0.05)$ increasing as the degree of risk increases. At the 1 st degree of risk the probability of occurrence of obstetric complications does not exceed $21.1 \%$, whereas already at the second stage it reaches $66.7 \%(\mathrm{p}<0.05)$.

Key words: hepatitis, prognosis, complications.

\section{Відомості про автора}

Міцода Роман Миронович - доктор медичних наук, професор, професор кафедри охорони материнства та дитинства факультету післядипломної освіти та до університетської підготовки ДВНЗ «Ужгородський національний університет». +380 (50) 529-13-36, rmitsoda@gmail.com. 